\title{
DIVORCE IN ENGLAND AND WALES: TIME FOR REFORM
}

\author{
Mary Welstead
}

\section{INTRODUCTION}

The clamour of voices crying out for reform of the law relating to financial provision on divorce is regularly heard. The judiciary, the academic community, lawyers and prospective divorcees have all expressed concern about the problematic nature of the current law and the urgent need for change. ${ }^{1}$ Yet these same voices rarely draw attention to the major defects inherent in divorce law itself. The battle for divorce reform which dominated the family law debate during the latter part of the 20th century appears to have been abandoned, along with the decision in 2001 by Lord Irvine of Lairg, the then Lord Chancellor, not to bring into force the major reforms to divorce law contained in Part II of the Family Law Act 1996 (see below). There is now an uneasy and, for the most part, a silent acceptance that the majority of spouses who want to bring their relationship to a legal end will find a way of doing so. The fact that they might have to resort to a massaging of the law, which may at times border on outright dishonesty, to secure their freedom and the right to embark on a new legal relationship, is largely ignored. Indeed in many family law textbooks and family law courses, the topic of divorce is barely discussed. It is viewed as an administrative process with little legal content to it. The few cases which do come before the courts are given similar scant treatment, even when they draw attention to the fundamental problems in the current law, a law which is both outdated and confusing.

This is not a satisfactory state of affairs. It is time that the long overdue reform of divorce law be (is) placed back on the Parliamentary agenda. With the advent of marriage for civil partners expected in the near future, changes will have to be made to divorce law to accommodate these couples. For instance, there is no concept of adultery in the law relating to the dissolution of civil partnerships. It would therefore be an appropriate moment for a

\footnotetext{
${ }^{1}$ See eg N Shepherd "Ending the Blame Game: Getting No Fault Divorce Back on the Agenda" (2009) Family Law 122; E Hasson "Setting a Standard or Reflecting Reality" (2003) Intl J Law Policy and the Family 338; G Langdon-Down "Divorce Law Reform: Doing the Splits" (2006) Law Society Gazette 20.
} 
complete overhaul of divorce law to be undertaken, rather than a piecemeal tinkering with it, to resolve such an anomaly.

\section{THE CURRENT LAW OF DIVORCE}

In 2003, Wilson J maintained that:

"In England and Wales divorce is not yet simply available upon joint demand immediately following a separation"

Theoretically, this statement may be correct but, in the critique of the current law below, it will be seen that many spouses are able to obtain a divorce because they both wish it, although they may have to go through a series of complex, oppressive and, at times, bizarre and illogical hoops to achieve their aim.

\section{The One Year Rule}

No matter how distressed a spouse is at the state of the marriage, no petition for divorce can be brought before one year has elapsed from the date of the marriage. ${ }^{3}$ This provision is based on the belief that marriage is an important institution which provides stability for the couple, their children, and for society. To allow an early exit, it is argued, would be to trivialise and undermine the institution. There are no exceptions to the rule even where a spouse is violent or turns out to be a criminal, or a fraudster with respect to an essential aspect of the relationship. There are circumstances where the rule can produce serious hardship although, of course, there is nothing to prevent a spouse from moving out of the family home and living separately until divorce becomes possible.

\section{One Ground for Divorce - Five Facts}

As most readers will be aware, there is only one ground for obtaining a divorce; s 1(1) of the Matrimonial Causes Act 1973 (the 1973 Act) provides that the relationship must have broken down irretrievably. However, it is insufficient to simply declare that this is so. The breakdown must be evidenced by one of the five facts in s 1(2) of the 1973 Act. Even where it is self-evident that the relationship has no future, the petitioner must still

\footnotetext{
${ }^{2}$ Bhaiji v Chauhun [2003] 2 FLR 485, at para [20].

${ }^{3}$ Matrimonial Causes Act 1973, s 3(1).
} 
establish one of the relevant facts. This has led to a common, but understandable, erroneous belief that the facts are the grounds for divorce.

Most partners will be able to find at least one of the facts, even if it may require a little imagination, some ingenuity, a significant expenditure of emotional energy, and, in some cases, money. There is no necessity to give any real evidence of the fact; a mere statement of its existence is sufficient. Because the divorce process is primarily an administrative one, it rarely involves the spouses in a court appearance. The forms are filled in by the petitioner ${ }^{4}$ or her lawyer and sent to the court where a judge will check them before agreeing to the grant of a decree. This means that it will be exceptional for a judge to challenge a petition unless fraud is suspected. ${ }^{5}$ Of course, it is always possible, but also most unusual, for a respondent spouse, to challenge the petitioner's statement and defend her request for a divorce. If he decides to do so, he is highly unlikely to succeed. The two decisions on defended divorce, discussed below illustrate this.

Rather illogically, the fact on which the petitioner relies need not be the cause of the breakdown of the relationship. In many cases, the fact may well be the symptom of the breakdown rather than its cause.

Where a petitioner is able to establish the existence of one of the relevant facts, it is still open, although admittedly unlikely, for a judge to decide that the marriage remains viable and decline to grant the order requested. If a respondent spouse defends the petition the judge will, inevitably, have to decide on both the reality of the fact pleaded and the viability of the relationship.

Divorce in England and Wales is primarily a fault-based process. Three of the five facts require the petitioner to accuse her spouse of a 'matrimonial offence'. This perpetuates the idea that relationship breakdown involves a perpetrator of harm and a victim. In reality, when relationships reach the point of breakdown, it is commonly acknowledged that it is, more often than not, the fault of both spouses or of neither. Many relationships simply reach the end of their natural life.

It is important to note that two of the three fault-based facts make it possible for a rapid exit to be made from the marriage - as little as three months in many cases. For those who view speed as an essential, there may be

\footnotetext{
${ }^{4}$ Throughout this article, to make for easier reading, the petitioner is referred to using the female gender and the respondent using the male gender; this approach also reflects the fact that more petitioners are women.

5 See eg Bhaji $v$ Chauhan above $\mathrm{n} 3$, where the judge became aware that the marriages had been entered into for immigration reasons and once visas had been obtained, petitions were brought to end the marriages.
} 
a temptation to plead one of these facts even though it may necessitate collusion with a respondent spouse or, maybe, even to indulge in a little judicious exaggeration. Occasionally spouses have made totally bogus claims. ${ }^{6}$

\section{Adultery}

The first of the fault-based facts is adultery; s 1(2)(a) of the 1973 Act requires that the respondent spouse has committed adultery and that the petitioner finds it intolerable to live with him. The petitioner need not give specific details of the adultery or give the name of the adulterer. Gone are the days of camera bearing private detectives following maids, delivering breakfast to the hotel room, to capture images of adulterous couples in bed. The petitioner relying on adultery has an additional task, imposed by case law, of stating that it is intolerable to live with the respondent for some reason other than the adultery. ${ }^{7}$ This is an unfortunate and almost certainly incorrect gloss on the statute.

If the spouses live together for longer than six months following the adultery, the petitioner will be deemed not to find it intolerable to live with the respondent. ${ }^{8}$ She will be unable to rely on the adultery fact unless, of course, the adultery is repeated.

If marriage between same-sex partners is legalised, the adultery fact would almost certainly have to be abandoned. It is hardly possible that a differential standard could be applied to heterosexual and same-sex spouses.

\section{Behaviour}

The second fault-based fact is behaviour; s 1(2)(b) of the 1973 Act, provides that the respondent must have behaved in such a way that the petitioner cannot reasonably be expected to live with the respondent. It is the fact which is most commonly relied on to prove irretrievable breakdown of the relationship. Past decisions have emphasised that it is not the respondent's behaviour which must be unreasonable but, rather, the expectation that the petitioner should continue to live with the respondent's behaviour. ${ }^{9}$ In spite of

\footnotetext{
${ }^{6}$ Ibid, at para 20 where the judge said: "This unusual hearing has exposed a concerted attempt to bypass the requirements of the present law and by the use of bogus allegations of behaviour to secure the immediate dissolution of marriages which have outlived their perceived usefulness"

${ }^{7}$ Cleary v Cleary [1974] 1 WLR 73.

${ }^{8}$ Matrimonial Causes Act 1973, s 2(1)(2).

${ }^{9}$ See eg Bannister v Bannister (1980) Fam Law 10.
} 
this, the second of the five facts is referred to regularly as 'unreasonable behaviour'. ${ }^{10}$

In Livingstone-Stallard $v$ Livingstone-Stallard ${ }^{11}$ Dunn LJ suggested a test which was both subjective and objective. He maintained that the correct question to ask was

"... would any right-thinking person come to the conclusion that this husband has behaved in such a way that this wife cannot reasonably be expected to live with him, taking into account the whole of the circumstances and the characters and personalities of the parties?"12

More recently this fact has been subverted to include behaviour on the part of the respondent if it can be seen as provoked by the petitioner. For example, in 2002 in an unreported decision, a 75 year old husband petitioned for divorce because his wife of 50 years reacted publicly and violently towards the news that he had been living a double life for more than ten years. He had a long-term mistress and child with whom he lived for part of the week and returned home to his wife at weekends. The wife, on discovering the affair, made malicious phone calls, contacted the press and spread the word noisily, and widely, about her husband's behaviour. However, she did not want the marriage to end at this late stage in her life - she was aged seventy-four - and was not prepared to petition for divorce herself.

The judge granted the husband a decree and said:

"I am satisfied that the respondent has been so overwhelmed by her hurt and outrage at the deception that she went over on to the attack in order to destroy the petitioner and his second family unit. However, no legitimate anger can reasonably lead to the conduct of the kind committed by the respondent. I am completely satisfied that the respondent's attitude was one of aggressive retaliation. The husband ruptured the marriage but the respondent, by her behaviour and attitude, caused the irretrievable breakdown. The question I have to ask myself is: would any right-thinking person come to the conclusion that this wife has behaved in such a way that this husband cannot be reasonably expected to live with her. To me the answer is undoubtedly yes. Apart from her family and close friends, there was no need for anyone to know about the family tragedy and certainly there was no

\footnotetext{
${ }^{10}$ See Savva v Savva [2012] EWCA Civ 579, at para 1.

${ }^{11}$ [1974] Fam Law 47.

12 Ibid, at 54.
} 


\section{DIVORCE IN ENGLAND AND WALES: TIME FOR REFORM}

need for her to spread the news . . unless her aim was to wound and humiliate." 13

It was a hard decision in both its practical and emotional effect on the wife and once again demonstrates that two of the three fault-based facts do, in effect, provide for divorce on demand.

If the petitioner lives with the respondent for longer than six months, she will not be able to rely on the behaviour complained of in any future petition. She will be deemed to have shown that she is able to tolerate her spouse's conduct. ${ }^{14}$

It is readily understandable why the behaviour fact is so frequently relied on in petitions. The nature of living in an intimate relationship is almost certain to give rise to behaviour which is irritating. It is arguable that the majority of partners could point to examples of behaviour which they could not reasonably be expected to tolerate. The possibility of relying on this fact, and achieving a rapid exit from the marriage, may lead encourage spouses to search through the dirty linen basket and parade one or more of its contents which is hardly likely to permit a civilised end to a relationship, or encourage cooperation in the upbringing of their children.

\section{Desertion}

The third of the fault-based facts is desertion. Petitions based on this fact are rare; the provision is positively Byzantine. Section 1(2)(c) of the 1973 Act provides that the petitioner must be able to prove that the respondent has not lived in the same household as her for two years, has no justifiable reason for living apart, and had the intention to remain permanently apart from him or her throughout that period.

A spouse may be found to have deserted the petitioner even if they both continue to live under the same roof but separately - not an easy task to achieve in a small house and most difficult to prove. ${ }^{15}$ There can be no desertion if the petitioner's conduct has in some way caused the respondent's departure or she has agreed to his departure. Where the respondent volunteers to return to the petitioner before the two years has elapsed and she refuses, without good reason, to resume living together, she will be held to be in desertion. It is not difficult to understand why a petitioner may feel unable to take back her deserting spouse. Trust may well have been lost but her refusal to comply with the respondent's request will mean that she can no longer end

\footnotetext{
${ }^{13}$ The Times, 1 September, 2000.

${ }^{14}$ Matrimonial Causes Act 1973, s 2(3).

${ }^{15}$ See Le Brocq v Le Brocq [1964] 1 WLR 1085.
} 
the relationship in reliance on her husband's original desertion. She may find that her husband will be able to reverse positions with her, become the petitioner and rely on his wife's desertion to obtain a divorce.

The deserting respondent does not have to communicate his intention to desert to the petitioner. This gives the petitioner the difficult task of discovering at what point the respondent who left without an intention to desert subsequently acquired one. Where a respondent who had the intention to desert but prior to the elapse of the two year period becomes mentally incapable of continuing with that intention, at the end of the two year period, he may be deemed to have held the intention for the requisite period of time. ${ }^{16}$ It may be the only way in which a petitioner can be helped but such deeming may seem a little unreal to many spouses who do not have familiarity with the Jesuitical ability of lawyers.

If the deserting spouse returns and is accepted back by the petitioner for a period longer than six months, the desertion is deemed to have ended. If the respondent returns for less than six months, the petitioner may still rely on the desertion but the period of resumed cohabitation does not count towards the requisite two year period. ${ }^{17}$

\section{The Fault-Free Facts}

Those spouses who wish to divorce but believe that they live in fault free relationships, or who do not wish to maintain that they are victims of a matrimonial offence, have two other options open to them: living apart for two years with an agreement to end the relationship or living apart for five years without such an agreement.

\section{Two Years Apart and Agreement}

Section 1(2)(d) of the 1973 Act provides that a petition for divorce may be brought if the petitioner and the respondent have lived apart for two years and they both consent to divorce at the end of that period. This fact provides for a non-acrimonious and private end to the marriage. All the royal divorces during the latter part of the $20^{\text {th }}$ century were based on this fact.

As with desertion, the parties may live under the same roof during the two-year period but they must conduct separate households. ${ }^{18}$ This is obviously easier to achieve in a royal residence than in the homes of most

\footnotetext{
${ }^{16}$ Matrimonial Causes Act 1973, s 2(4).

${ }^{17}$ Ibid, s 2(5).

${ }^{18}$ Ibid, s 2(6).
} 
potential divorcees. The case law has tended not to take into account the realities of everyday life. ${ }^{19}$ During times of economic recession, and where the couple have children, it will often be difficult to maintain two separate households. It may be essential and more civilised to share the practical every day arrangements such as cooking, eating and laundry. In every other way the spouses may well be living apart.

The petitioner must state the date on which she and the respondent began living apart and give the reason for doing so. It is not necessary to show that there was a matrimonial fault of some sort which precipitated that decision. The petitioner must also state the circumstances in which she concluded that the marriage was at an end.

The courts have rather controversially imported an additional requirement into s 1(2)(d) of the 1973 Act. In Santos $v$ Santos $^{20}$ for example, it was held that the two year period only commences when one spouse recognises that the marriage is at an end although it is not necessary to communicate that realisation to the other spouse. Such an approach could mean hardship for those spouses who separate on a trial basis and do not discover that the marriage is at an end until the two years have elapsed. It fails to recognise the imprecise nature of human relationships. Partners who have decided to live apart may continue to harbour a faint hope that their relationship may not be finally over. Often it is only when one spouse wishes to enter into a new legal relationship that there is an acceptance that the marriage is truly at an end.

Although the decision in Santos has not been strictly adhered to, the spouses must at least form an intention to live apart at the beginning of the two-year period and continue to live apart until they give their consent to the grant of the decree at the end of the two years.

If the spouses move back to live with each other for more than six months, they must recommence the two year period of living apart afresh. If they resume living together for less than six months and wish to proceed with the divorce, the time together will not count towards the requisite two years. ${ }^{21}$

In spite of some of the uncertainties of what it actually means to live apart for two years, it would seem that this is the most civilised of all the ways of ending a relationship. It gives the spouses time to consider whether they really do wish to end their marriage. It allows them to plan for their future and that of any children of the relationship.

\footnotetext{
${ }^{19}$ See eg Mouncer v Mouncer [1972] 1 WLR 321, cf Fuller v Fuller [1973] 1 WLR 730 .

${ }^{20}$ [1972] Fam 247.

${ }^{21}$ Matrimonial Causes Act 1973, s 2(5).
} 
Petitioners who are unable to rely on any other fact have to rely on what is often referred to as the fact of last resort - living apart for five years. ${ }^{22}$ This fact is not, as has been suggested, ${ }^{23}$ a Casanova's charter for men wishing to divorce their innocent wives unilaterally. The majority of those who rely on this fact are women.

The spouses may resume living together for a period of six months. If they remain together for longer, and the relationship subsequently breaks down, the five years must start afresh. If they live together and part before the six months has elapsed, they may not count the time spent together towards the requisite period of five years. ${ }^{24}$

There is no requirement that the respondent must consent to the decree but he may attempt to prevent the divorce by pleading the defence of grave hardship. ${ }^{25}$ This defence allows a respondent to claim that a decree will result in grave financial or other hardship to him and that it would in all the circumstances be wrong to grant the decree. The judge has a wide remit to take into account such matters as the conduct of both spouses, their interests and those of any children, or other persons concerned.

Grave hardship of both an emotional and a financial nature is almost inevitable on relationship breakdown but the type of hardship envisaged by the 1973 Act is more than that. The hardship must flow from the divorce decree rather than the breakdown of the relationship. Case law reveals how difficult it is to prove the relevant connection. The defence has been used primarily as a bargaining tool by respondents; they have threatened to plead the defence in return for a larger financial settlement. Now that pension sharing is possible on divorce, the defence has been reduced significantly in importance.

No respondent who has pleaded non-financial grave hardship has ever succeeded in preventing the grant of a decree. In Banik $v$ Banik, ${ }^{26}$ the court rejected the respondent's claim that her community would ostracise her and she would never be able to re-marry. It said that she would have had to:

\footnotetext{
${ }^{22}$ Ibid s 1(2)(e).

23 R Deech "Divorce and Empirical Studies" (1990) LQR 229; R Deech "Divorce a Disaster (2009) Family Law 1049.

${ }^{24}$ Matrimonial Causes Act 1973, s 2(6).

25 Ibid s 5.

${ }^{26}$ [1973] 3 All ER 45.
} 


\section{DIVORCE IN ENGLAND AND WALES: TIME FOR REFORM}

"...satisfy the court that it would be a real hardship to her if the marriage was dissolved, not just something which made her unhappy or distressed her, or which she regarded personally as immoral or contrary to the rules of her community." ${ }^{, 27}$

Even if a respondent is able to clear the difficult hurdle of proving grave hardship, the court retains a discretion whether or not to grant the decree. It has to balance out the hardship to the respondent if the decree were to be granted against the injustice to the petitioner if it were to be refused. ${ }^{28}$ The decision in Julian $v$ Julian $^{29}$ is one of the rare cases in which the court declined to grant a decree. It held that it would not be wrong to prevent the petitioner, who was unwell, from the possibility of remarrying. His wife, who was also ill, was found to be more in need of protection from financial hardship which would be the consequence of the grant of the decree.

\section{Reconciliation}

The current legislation pays lip service to the possibility of rescuing relationships. Section 6(1) of the 1973 Act $^{30}$ provides that solicitors must state whether they have discussed reconciliation with a client who has sought divorce advice and whether she has been given information about agencies which may be able to help. It is unknown how many relationships have been saved by these provisions but it is assumed very few. The provisions have been criticised as being ineffectual and paternalistic.

\section{Defended Petitions}

Although few respondents attempt to defend a petition, the ones who have tried to do so have been most unsuccessful. If one partner wants a decree of divorce, no matter how desperate a respondent is to save the marriage, defending the petition is not going to give him what he wants. Rather, the very act of defending the petition is likely to be so acrimonious that it will actually ensure that the decree will be granted.

Two important decisions illustrate the likely outcome of defending a divorce.

\footnotetext{
${ }^{27}$ Ibid at para 50.

${ }^{28}$ Matrimonial Causes Act, s 5(1)(2)(b); see Brickell v Brickell [1974] Fam 31.

${ }^{29}$ [1972] 116 SJ 763.

${ }^{30}$ Matrimonial Causes Act 1973, s 6, Family Procedure Rules, rule 7.6.
} 
In Hadjimilitis (Tsavliris) $v$ Tsavliris $^{31}$ the respondent spouse was a wealthy ship-owner who decided to defend his wife's petition for divorce; she had relied on the behaviour fact. The court found that he had treated his wife with criticism and low warmth, controlling and undermining behaviour, public humiliation and lack of respect, insight, sensitivity, understanding and sympathy.

As a consequence, she had become depressed and stressed. Her husband's reaction to this was to demand that she pull herself together. She had no financial resources of her own and her husband insisted that she ask him or his secretary for money whenever she needed it. He refused to possess a key to the family home so that at whatever time he arrived home, his wife would have to be available to let him in. This allowed him to control her activities and ensure he always knew where she was when he was out of the house.

In defending the petition the husband accused his wife of having been unfaithful to him. He claimed that she had merely married him for financial reasons; had not supported him either emotionally or practically; was a bad mother, and a drug taker.

The court held that such accusations merely confirmed the wife's statements about her husband's behaviour. They so undermined the relationship that no one could be expected to live with a husband who made such allegations. The wife was granted her decree.

In Savva $v$ Savva $^{32}$ the husband, a chartered surveyor aged sixty four, attempted to prevent his wife, a biology teacher aged fifty eight, from divorcing him. The couple had been married for thirty four years. The wife had petitioned for a decree of divorce in reliance on the behaviour fact. $\mathrm{Mr}$ Savva maintained that his wife had acted angrily and hastily in petitioning for divorce. He maintained that he had not exhibited unreasonable behaviour and that his marriage had only temporarily broken down. He claimed that his wife had suffered a breakdown and was confused, otherwise she would not have petitioned for divorce or criticised his behaviour. He believed that the court should have insisted on psychiatric evidence to show how disturbed she was. Furthermore, he suggested that her instability showed that she lacked the capacity to instruct a solicitor. He claimed there were practical reasons why he and his wife did not share a bedroom. He tried to explain that the house was in a mess and his wife needed her own space.

Mr Savva, argued that the divorce law in England and Wales did not do enough to encourage couples to remain married; uncorroborated evidence about spousal behaviour was accepted by the court. He urged that a one-year

\footnotetext{
${ }^{31}$ [2003] 1 FLR 81.

32 [2012] EWCA Civ 579.
} 
cooling off period should be introduced to prevent marriages being brought to a rapid end without serious thought (as partly envisaged by Part II of the Family Law Act 1996), that way, he maintained, a lot of angry women would be forced to let their anger abate and consider calmly the future of their marriage and their family before resorting to discussions with solicitors.

The Recorder, Judge Cudby rejected Mr Savva's view of the marriage. Rather, she found that his wife struck her as upright, honest and, not unsurprisingly fed up with all that had been going on in her marriage. She did not perceive her as in any way psychiatrically unwell or in need of any assistance.

Judge Cudby expressed the view that it was always hard when one party believes that the marriage has ended and the other does not. She commented that it was sad that Mr Savva could not accept that his long-term marriage had broken down and was seeking excuses rather than facing the truth. Nevertheless, she granted Mrs Savva a decree of divorce. Mr Savva sought leave to appeal the decision.

In the Court of Appeal, Mr Savva argued that Judge Cudby should not have made findings about his and his wife's emotional and mental states without the benefit of independent evidence from disinterested parties. He felt his wife was unable to give reliable evidence herself about her mental state and about the events of the marriage. He also maintained that the Recorder had wrongly concluded that the marriage had broken down irretrievably but at the same time had questioned the accuracy of the wife's evidence on the length of time she and her husband had occupied separate bedrooms. The wife had maintained that this state of affairs had gone on for at least eight years whereas the husband maintained it was only for three years.

The Court of Appeal confirmed the Judge's approach and said that it mattered not whether the separate occupation of bedrooms had endured for eight or three years, it was clearly symptomatic of the irretrievable breakdown of the relationship.

The husband finally maintained that his wife had not obtained a certificate of reconciliation. He thought incorrectly that this document placed an obligation on his wife's solicitor to point her in the direction of counselling in an attempt to save the marriage. Lady Black corrected this view and explained that the solicitor is merely required to state that he has mentioned the possibility of reconciliation to his client. Lady Black pointed out that it was unlikely that a certificate had not been obtained but, in any event, its absence would not prevent a petition from being granted once the Judge had found that the marriage was no longer viable. She refused to grant the husband leave to appeal the grant of the decree. 


\section{REFORM OF THE LAW}

\section{A Previous Attempt to Reform - Family Law Act 1996 Part II}

After long debate, Parliament finally enacted Part II of the Family Law Act 1996 which introduced the concept of 'no fault divorces'. Spouses were to attend information meetings at which they would learn about, inter alia, reconciliation, marriage counselling, mediation, the law and lawyers, the importance of children's welfare, the division of financial assets. Pilot schemes of such meetings took place but they were not successful. In June 1999, the Lord Chancellor decided that the preliminary results of the schemes were so disappointing and did not achieve the aim of saving marriages or persuading spouses to mediate. The information meetings were viewed as too rigidly defined; spouses wanted information appropriate to their own specific circumstances. The meetings came too late; marriages were already in a major state of decline by the time the spouses attended them. There was also a problem in finding sufficient numbers of experienced counselors and mediators. When the final evaluation reports became available, the Lord Chancellor announced in 2001 that the Act would not be brought into force (except for s22 relating to relating to the funding of marriage support services, which had already been brought into force and would remain so) and that the Government would invite Parliament to repeal it once a suitable legislative opportunity arose. $^{33}$

\section{The Way Forward}

It is abundantly clear that the current divorce law is confusing, misleading, outdated, and excessively legalistic. It is rare for anyone to be prevented from obtaining a decree but, for the most part, the law does not allow for a calm and civilised end to a relationship. This is particularly so where there is no obvious reason, or fault on the part of either partner, for its breakdown. Reform is essential.

\footnotetext{
${ }^{33} 21$ April 2010 HL Deb 17 June 1999, http://www.dca.gov.uk/family/fla/flapt2.htm; B Hale "The Family Law Act 1996: Dead Duck or Golden Goose" in S Cretney (ed) Family Law: Essays for the New Millennium (Blackwell Synergy, 2000).
} 


\section{Marriage Reform}

In spite of the high divorce rate in England and Wales, ${ }^{34}$ marriage is still regarded by the majority of people as the gold standard for stable familial relationships. Part of the Government's determination to legalise same-sex marriage is based on this view. Any attempts to reform the law relating to divorce must consider first the law relating to marriage. If marriage is an important institution for society as well as for the individual, it must not be trivialised or undermined. It is a relationship which should not be undertaken without serious thought. At the heart of divorce reform is the need consider whether the institution of marriage should be reformed, particularly prior to its inception.

At present, it is not difficult to marry. One may do so without any understanding of the relationship contract to which the spouses are giving their agreement. They need to understand its legal consequences and responsibilities as well as the benefits given to them by the State for agreeing to undertaking those responsibilities (it must be acknowledged that many of the benefits are given merely for entering into marriage regardless of whether the responsibilities of the contract are fulfilled). It must be questioned how many of those who embark on marriage understand the precise nature of the contract. It is not written down in any positive form, rather, couples are left to discover it in piecemeal manner as they journey through their marriage. It is usually only when the relationship begins to experience difficulties that the spouses learn to their surprise what it is that they unknowingly agreed to (sic) during the marriage ceremony. Suddenly, the intricacies of the law and its consequences for them become visible.

Many couples spend a considerable period of time often several years, planning their perfect wedding day; little is left to chance; expenditure is boundless. But how many of these couples give a similar amount of attention to the nature of the relationship into which they are entering? Too often it is argued that it would be unrealistic to expect couples who are about to commit themselves to each other to contemplate the possibility of problems and the legal consequences of them. The proponents of this view believe that all couples are entitled to their romantic dreams. They should not have the magic of their special day ruined with negative thoughts; spouses will find out soon enough what marriage means.

It would be better if it was compulsory for all couples to consider the consequences of the contract of marriage, and to do so prior to making a legal

\footnotetext{
${ }^{34}$ In 2010 the divorce rate in England and Wales increased by 5.7 per cent to 11.1 divorcing people per thousand married population, compared with 10.5 in 2009 (Divorces in England and Wales 2011 Office of National Statistics 2011).
} 
commitment to each other. One possible way forward would be to demand that all couples should have to give notification to a Registrar of Marriages of their intention to marry at least three months before the ceremony. At the time of notification, they would be provided with written information explaining the serious legal implications and responsibilities of marriage, how to legally bring it to an end, should they wish to do so at some point in the future, and the consequences, including the financial ones, of such an action. Two months prior to the wedding, the prospective spouses would each have to sign a separate legal document, witnessed by a lawyer, stating that they have read the information given to them and that they understand what it means to commit to each other in marriage. ${ }^{35}$ These signed statements would be deposited with a Registrar of Marriages.

\section{Divorce Reform}

Given the current high divorce rate, it would seem pointless to try to lower it by way of a difficult and complex divorce law. It is inevitable that some spouses will not want to remain married, and attempting to force them to do so is unrealistic. Any law reform must reflect this. A way forward must be found which respects the importance of marriage as an institution and allows those who wish to exit it to do so responsibly, thoughtfully, and in a civilised non-confrontational manner, and not in thoughtless great haste. It is essential that any new divorce law must protect, in so far as possible, the couple, their children, and society as a whole, from the damaging effects of ending relationships. It must be acknowledged that damage-free divorce is probably impossible to achieve even if both spouses conclude at the same time that they wish to leave the relationship.. Children are never happy at the prospect of their parents leaving each other even if they find it difficult to bear the marital disharmony which so often precedes the parental decision to part. For the majority of spouses, there are serious financial implications on divorce; their standard of living will be significantly lower than during the marriage. No ref necessary I have said that it is true for the majority of spouses-only the rich tend not to suffer

A civilised divorce law should be time-based and only time-based; there should be no other ground for divorce. A prescribed period of time should have to elapse between the decision by a spouse (or both spouses if they are in

\footnotetext{
${ }^{35}$ It may be that those who wish to sign a pre-nuptial financial agreement could also be permitted to so at this stage and, thereby exempt themselves from the financial provisions imposed by the current law on spouses who divorce - a law which is also in urgent need of reform.
} 
agreement) to leave the marriage and the grant of the divorce decree. It should not be less than one year and not more than two years; eighteen months would be an acceptable compromise. A spouse, or both spouses if in agreement, would have to sign a simple statement, indicating a wish to end the marriage, and deposit it with the Registrar of Marriages. There should be no requirement to state or prove that the marriage is no longer viable. It cannot be the task of the law to determine whether that is so.

There would then follow a prescribed period of time, at the end of which a petition of divorce would be presented to a judge, accompanied by a statement of the couple's proposed resolution of their financial affairs and their arrangements for the future residence and financial support of any children of the marriage.

The lapse of a period of time prior to the grant of a divorce would reflect the importance which the State and society attaches to marriage. It would give both spouses time to consider their relationship and either reconsider a decision to end it or begin to adapt to the possibility of, and plan for, a new future. The prescribed period would permit them to put in place arrangements for their children and organise their financial affairs.

Such a reform has the advantage that there would be no acrimonious accusations of fault or arguments about whether the marriage has broken down or not, there would simply be the requirement that at least one of the spouse wishes to leave the relationship.

There is always the possibility that a couple, deliberately or otherwise, would not make the necessary financial arrangement, or decide on the future residence and financial support of the children, within the 18 month period. In such cases, the court would have to be involved and a further three month period would be given to the couple to resolve any outstanding matters. At the end of the three month period, the divorce would normally be granted whether or not the spouse's arrangements had been finalised. Exceptionally, a judge might declare that a decree of divorce could not be given until a couple's affairs had been resolved satisfactorily. In normal circumstances, to allow the process to continue beyond two years would permit a spouse to deliberately sabotage the divorce as a bargaining tool to determine a child's residence or to gain a larger financial settlement.

There will be critics who are certain to suggest that an eighteen month or two year waiting period is too long a time to wait for a divorce, particularly, if the spouses are forced to occupy the family home together until the financial arrangements have been resolved. Whilst recognising that continuing to live together is not easy for a family on the point of break up, the reality is that already many spouses have to do precisely that. Even those spouses who obtain a rapid divorce in reliance on the adultery or behaviour fact often have 
to live together whilst they wait to sell the family home or find alternative accommodation.

The advantage of divorce being dependent on the lapse of a period of time would ensure that all potential divorces would be treated equally. It would prevent people using the adultery or behaviour facts to obtain a decree precipitously and remarry rapidly before they have time to process the end of their previous marriage and make satisfactory arrangements with respect to the responsibilities they took on when they married. It would not, of course, prevent people from entering into a new non-marital relationship.

A different group of critics is likely to claim that the proposal to simplify divorce, if enacted, would undermine marriage. It would allow people to leave the relationship merely because they wish to do so.

The reality is that it is clear that the law already permits this although in a more convoluted and disingenuous manner and it is time to end this unsatisfactory state of affairs. 